\title{
QUALITATIVE ANALYSIS OF EFFECTS OF MANAGERIAL PERCEPTION ON OPEN INNOVATION
}

\section{INTRODUCTION}

The open innovation concept was brought by Chessbrough (2003), and since then, the term was implemented widely among both public institutions and commercial firms (1, 4264). As public entities are required to provide services efficiently and effectively (not only in terms of socio-economic values for society but also to assure sustainability in the long run), they also need to be innovative. Public institutions are considered open in innovation by default (mainly observed public research institutes within this research). Considering Chessbrough concept of open innovation, there is a lack of connection between inbound and outbound openness of many public institutions. Many public institutions are now considering ideas and knowledge from the outside world (using outbounds). In the case of Challenge.gov, the contest by U.S. Federal Government they seen a huge success of innovation $(2,726-745)$. The public institutions also adopted the open innovation concept into their organizations (having in mind that public institutions generally are open, which represents one of their goals to support and advance economic and social scientific contribution for society). However, there are different modes of use of open innovation, and therefore, it might be required to understand better how those institutions (more precisely - managers and academicians who are employed at Public institutions) see and measure the success of open innovation in their organizations. This paper deals with particular understanding and views of Academicians and managers within Public Institutions (biotechnology industry) of open innovation success meaning with their - perceptions. In this research, experts from Sofia Agrobiotech Institute (Universite Cote D'Azur,

\section{SUMMARY}

Key words: Managerial perception, corporate sustainability, public institutions, agrobiotechnology.

This paper deals with the aspects of managerial perception and understanding of the success of the open innovation concept and its impact on the sustainability of public institutions. Major French (and global) Agrobiotech Institutes were selected for the qualitative analysis to understand its managers' position in terms of open innovation concept and how it might contribute to the sustainability of the public institutions. Findings indicate that balanced activities of creation of social values and commercialization of the effects are perceptions for sustainability strategy of academicians and managers that were interviewed.

' SKEMA Business School, Francois Grosso 7, Nice, France. E-mail: milorad.stamenovic@skema.edu. 
France) and French National Institute INRAE have undergone questionnaires in order to qualitatively assess the managerial perception of success and its measurement of open innovation concept in their organizations. If social benefit prevails under profit-oriented benefit, it is questionable whether Public institutions are sustainable in the long term? As one of the examples that triggered this research, we would like to remind you of Ogura oilseed (developed by INRAE), for which the social benefit of production and implementation on the market was 1,2 billion EUR $(3,5)$. However, the public institution INRAE that produces this particular seed needed around 15 years to reach the break-even point without any additional benefits from this profitable project (3). By this example, it was confirmed there might be further understanding of the success of the open innovation concept in public institutions, and they can be seen as successful or not in terms of adopting open innovation. In addition, it might be noted there is a different understanding of public institution success in open innovation concept among various institutions. For exploring these views, semi-structured interviews will be conducted at prestigious public sector institutions, i.e., INRAE and at Agro Biotech Institute, both located in the Republic of France.

\section{LITERATURE REVIEW}

The role of managerial perception is the essence of this paper as it deals with an understanding of the success of the open innovation concept and its impact on the sustainability of public institutions. It is well known that human beings are shaped under the influence of both concrete and abstract factors (4). Jung defines perception in terms of sensing, interpreting, and appreciating physical and social processes (4). Berelson and Steiner define perception as a: "complex process by which people select, organize and interpret sensory stimulation into a meaningful and coherent picture of the world" $(5,88)$. The need for analyzing perceptions is important due to the fact that differences in perceptions among organizational members lead to questionable shared value systems (e.g. strategy development culture) (4). Practically, differences in shared values (through perceptions) might lead to changes in development programs (4). The role of managerial perceptions in the decision-making process and strategy formulation has been acknowledged by many scholars (6); (7);(8);(9). The critical link is that strategy change through perception might lead to increased and efficient sustainability (financial and other) in multiple ways.

When it comes to sustainability - "corporate sustainability is a complex concept and refers to the practice of enhancing ecological, 
social, and economic goals to meet the needs of both current and future generations" $(10,298)$. In addition, managerial perception is not recognized as one of the leading factors, and there is ample space for further research on those topics (11). According to $(12,259)$ :

"Sustainability initiatives are perceived, planned, and executed by managers of organizations, but academics have acknowledged that little is known about how managers of firms perceive the nature, relevance, and impact of sustainability activities."

Moving to the direction of project success based on the open innovation concept at public institutions, scholars are defining different approaches for measuring the sustainability of public institutions. One of the crucial approaches suggests managerial practices and project efficiency through endogenous and exogenous factors (13). In terms of organizations, it was noted struggling to evaluate the role of the innovation networks for improvement of their performance, and many businesses failed to get profit from open innovation. It shows that open innovation itself is not a success, and in fact, it should be translated into profit. Edelbroek et al. examined the relationships between transactional and transformational leadership on the one hand and the quality of the open innovation process as perceived by employees on the other (14). Sivam et al. studied factors of contribution for booming open innovation arena and found that factors like culture, leadership, and strategy are the main drivers to an open innovation arena, highlighting culture as the most important one (15). They argued that these are the factors that could lead to the success of open innovation. The external knowledge search increases the innovative performance, while constraints decrease innovative performance through open innovation. Also, researchers found that top management's knowledge value and knowledge-creating abilities have a positive impact on open innovation, and hence small and medium enterprises can perform better in terms of innovation (and are more successful) (16). Comparing to observed commercial companies, it was noted that those companies are measuring open innovation success using different value contributed for the firm, rather than concentrating on social impact (or even consumers impact). Namely, for commercial companies, the time distance between innovation exposure to the public and time of created collaboration is essential. From the side of public institutions, the socio-economic impact is a much more relevant factor. However, the number and quality of research publications that lead to innovation are applicable for both commercial and public institutions. Therefore, considering the above, the central point of research is to understand how experts involved in work at Public Institution's percept success and sustainability. 


\section{METHODOLOGY}

The research question we were considering was: "What are managerial perceptions of measuring the success of the open innovation concept in public research institutions and its effect on sustainability?". As this research was structured as a case study, we analyzed two institutions whose experts had undergone the interview. Selected institutions for interviewing based on institution competencies are INRAE - French National Institute of Agricultural Research and Agrobiotech Institute (city of Sofia Antipolis, France).

The first institution - INRAE (French National Institute of Agricultural Research), is considered the best European agricultural research institute. It is globally ranked as $2^{\text {nd }}$ best in agronomy, plant sciences, and food science and technology. In addition, INRAE is positioned as $1^{\text {st }}$ globally in terms of dairy and animal science. INRAE is a publicly owned institute based in France and one of the significant knowledge generators within the scope of agricultural work in the Republic of France. Primary goals are identified within enabling freedom of choice to people and the ability to innovate (17). In 1989, Pierre Douzous launched the first major interdisciplinary programs at INRAE: Agrobio and Agrotech. In 1992, after the first visit to INRAE as deputy director-general, Guy Paillotin returned as president at the request of the minister of research Hubert Curien and will remain so for eight years. In these times of health crisis, in the 1990s, and controversy over transgenic plants, Guy Paillotin wonders about the existence of a new contract between agriculture and society. It places the consumer citizen at the center of the institute's concern. The direct extraction of DNA from soil samples marks an important step in the harmonization of methods for the quantification and identification of the soil microbial communities. Developed at the soil and environment microbiology laboratory at INRAE in Dijon, this extraction method was the subject of the standard (ISO11063) in 2009. Developed at INRAE since 1996, the STICS model has served as the basis for the design of many other integrative models. It is available free of charge on the website of the Agroclim research unit and current concerns around a hundred users, mainly for research and teaching purposes (17) INRAE is specialized in food, nutrition, agriculture, and environmental issues. The focus of INRAE is to achieve competitiveness, regional land use, health, sustainable development, and bio-economy (17). As initially Public Institution is oriented to the openness of innovation to have a larger contribution to science and society. INRAE case of 
Ogura Oilseed (mentioned in the previous text) was one of the triggers for this analysis as it shows the utterly non-profit-oriented approach in open innovation and, therefore, it shows potential issues in creating a sustainability model.

The second institution assessed is Agrobiotech Institute (Sofia Antipolis). The Institute Sophia Agrobiotech represents an international research institute funded by INRAE, Université Côte d'Azur and CNRS. This institute is created as a member institute of Université Nice Sophia Antipolis. In addition, this institute cooperates with INRAE on a variety of projects and has been specialized in the discipline of biology (agriculture, agronomy, and environment). The main contribution of this institute is in generating knowledge in plants health and improvement of the human environment (18). Situated at the interface of Environment and Agriculture, the main research topics concern the study of plant interactions, pathogens, and symbionts and their dynamics in time and space. The institute brings together comparative solid, evolutionary, and functional genomics in community ecology and agronomy. The institute aims to address some of the challenges offered for agricultural research in the environmental management of agroecosystems. The ultimate goal is to integrate this knowledge into developing innovative agronomic strategies (integrated pest management, biological control).

Questionnaires were provided to experts in the field from both institutions. The interview was semi-structured, and data were analyzed upon transcription and coding. In order for qualitative data to be analyzable, it must first be grouped into meaningful patterns and/or themes for observation. This process is the core of qualitative data analysis and was generally conducted through content analysis (the type of analysis that is highly dependent on the nature of the research questions and the type(s) of data collected).

Content analysis is carried out by coding the data for certain words or content; Identifying patterns; Interpreting meanings. This type of coding is done by going through all of the text and labeling words, phrases, and sections of text (either using words or symbols) that relate to research questions of interest. After the data is coded, those are sorted and examined by code to look for patterns. In this work, we follow "Gioia's method" and analyzed interviews, and in each interview, by going through sentences and phrases, we codified in terms that related to our research question, and then for interviews, we interpreted these terms and meaning after re-consideration. 


\section{RESULTS}

Model is based on the literature and research that is showing that managerial perception about certain topics has a significant impact on strategy change. If we consider that strategy might be changed in a way that public institutions achieve better sustainability indicators, then we should consider managerial perception as relevant for the sustainability of the public institutions. In this particular case, where we assess managerial perceptions regarding the success of the open innovation concept in the public institutions, we have shown a significant impact of the managerial perceptions on sustainability through influence on strategic aspects of the institution. Strategic aspects that might be preferable in terms of sustainability of organization are better cooperation with commercial sector, more efficient approach to projects, innovative managerial concepts, boosting motivation, etc. Sustainability depends on many factors, and many authors define endogenous and exogenous factors as relevant. Depending on the research niche, those factors might be differently defined, but in this paper, we are concentrating on the overall impact of internal and external factors that affects the perception of managers and leads to strategy change relevant to sustainability.

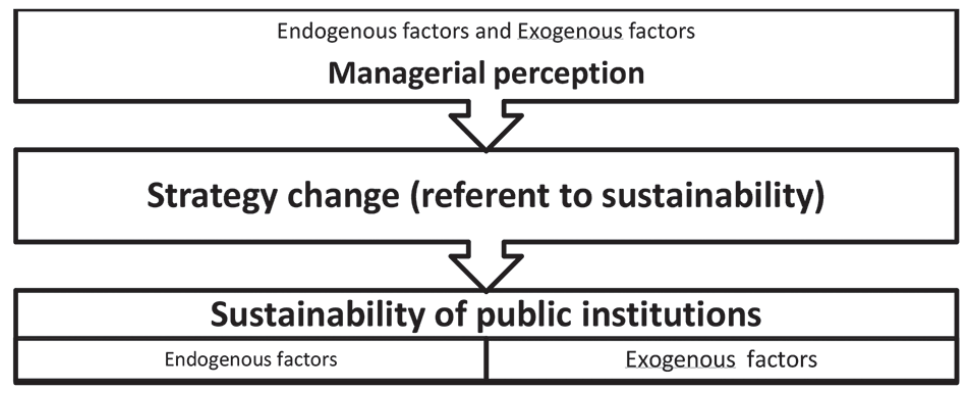

Figure 1. Conceptual model of the influence of managerial perception on organization sustainability 


\begin{tabular}{|c|c|c|c|}
\hline I Order concepts & 2nd order themes & \begin{tabular}{|c|} 
Agregate/Overarchin \\
g dimensions
\end{tabular} & \\
\hline $\begin{array}{l}\text { *mostly working on publishing our academic research that } \\
\text { is open } \\
\text { *there is pressure on timelines for new discoveries, by } \\
\text { reducing time. } \\
\text { *the meaning of fundamental research is less and less } \\
\text { important. } \\
\text { *we are providing research this for free in order to have } \\
\text { applied results or expending of our research }\end{array}$ & $\begin{array}{c}\text { Open innovation, } \\
\text { open rese arch - } \\
\text { innovation } \\
\text { development }\end{array}$ & & \\
\hline $\begin{array}{l}\text { *boosting motivation is also based on work with different } \\
\text { people (higher diversity) } \\
\text { *In last period of time, there is pressure on timelines for } \\
\text { new discoveries, by reducing time. } \\
\text { *And people and politics want that we work on the } \\
\text { applied science due to these kind of things. } \\
\text { *Many times we cant see effects immediately, sometimes } \\
\text { in } 20-30 \text { years } \\
\text { *Interdisciplinarity help us to boost research in many ways }\end{array}$ & Boosting motivation & \begin{tabular}{|c|} 
Perception on \\
importance for \\
Dquelopment of new \\
technologies \\
(internal factor)
\end{tabular} & \\
\hline $\begin{array}{l}\text { *we are now trying to implement new managerial models } \\
\text { that might help in better use of patents } \\
\text { today with Innovation and private owners are going to be } \\
\text { involved really early in the development process and } \\
\text { patent rights and shares should be defined at early stage } \\
\text { *We develop more and more projects in any integrative } \\
\text { way with the people, for example, in a law and social } \\
\text { science management and this might help us to implement } \\
\text { better strategies }\end{array}$ & $\begin{array}{l}\text { New managerial } \\
\text { methods }\end{array}$ & & $\begin{array}{l}\text { Changing in strategy } \\
\text { that results in long } \\
\text { term sustainability of } \\
\text { Public institution } \\
\text { throogh Open } \\
\text { innovgtion concept }\end{array}$ \\
\hline $\begin{array}{l}\text { *For us socio economic benefit for society is on first place } \\
\text { and we have prices calculations about it. } \\
\text { *We are measuring success with specific tools that are } \\
\text { incorporated within our projects and we are mostly } \\
\text { concerned about socio economic impact (impact on } \\
\text { environment on social politics etc.) }\end{array}$ & $\begin{array}{c}\text { Socio-economic } \\
\text { benefit }\end{array}$ & & \\
\hline $\begin{array}{l}\text { *we also collaborate with companies } \\
\text { *We had large success cooperating with private } \\
\text { companies } \\
\text { *target is patented by either the companies or by INRA } \\
\text { *We could have collaboration with companies and we } \\
\text { would share ownership of the new business }\end{array}$ & $\begin{array}{l}\text { Collaboration with } \\
\text { companies }\end{array}$ & $\begin{array}{c}\text { Perception on } \\
\text { importance for } \\
\text { transfer of } \\
\text { technologies } \\
\text { (internal\&external) }\end{array}$ & \\
\hline $\begin{array}{l}\text { *You can have innovation resulting from the collaboration } \\
\text { between one or several factors and you can invite all } \\
\text { involved in the project in order to have better results in } \\
\text { discovery } \\
\text { *you need to improve the innovation } \\
\text { *then we'll patent an innovation based on the result that } \\
\text { we publish } \\
\text { *You can have imnovation resulting from the collaboration } \\
\text { between one or several factors }\end{array}$ & $\begin{array}{c}\text { Collaboration for } \\
\text { imnovation with } \\
\text { researchers and } \\
\text { other non } \\
\text { commercial entities }\end{array}$ & & \\
\hline $\begin{array}{l}\text { *as we are transferring technology, then we are also } \\
\text { looking into financial benefits } \\
\text { *We are now more open to different uses of patents and } \\
\text { different collaborations. } \\
\text { *For us socio economic benefit for society is on first place } \\
\text { and we have prices calculations about it. } \\
\text { *When INRA request, we provide researches and for } \\
\text { sure this should be patented } \\
\text { *We had large success cooperating with private } \\
\text { companies based on research done by our institute } \\
\text { *Our partners created companies and now they have large } \\
\text { successful companies } \\
\text { *we develop some patents if other entities are interested, } \\
\text { but our main objective is research }\end{array}$ & $\begin{array}{c}\text { Changing } \\
\text { perception: from } \\
\text { financial de pendent } \\
\text { to } \\
\text { conmercialisation }\end{array}$ & $\begin{array}{r}\text { Perception on } \\
\text { importance of } \\
\text { systainability } \\
\text { (internal and } \\
\text { external) }\end{array}$ & \\
\hline $\begin{array}{l}\text { *In past - transfer of the technology at late step. But this } \\
\text { is not a case today with Innovation and private owners are } \\
\text { going to be involved really early in the development } \\
\text { process and patent rights and shares should be defined at } \\
\text { early stage. Another issue with this case was very long } \\
\text { time of development. } \\
\text { *We are interested in developing science and social } \\
\text { contribution } \\
\text { *Our success is mainly in terms of academic success and } \\
\text { new research and contribution to science and society. }\end{array}$ & $\begin{array}{c}\text { Awareness of issues } \\
\text { concerning } \\
\text { sustainability }\end{array}$ & & \\
\hline
\end{tabular}

Figure 2. Qualitative method data analysis defining $1^{\text {st }}, 2^{\text {nd }}$ order concepts and Aggregate/Overreaching dimensions 
Findings indicate that balanced activities of creation of social values from one hand and commercialization of the effects are perception for sustainability strategy of academicians and managers that were interviewed. Social impact and values of societies are presented as most important for public institutions, but commercialization was also underlined as required to achieve sustainability and, therefore, strategy change due to evident managerial perception for more efficient and financially sustainable performance of public institutions.

\section{CONCLUSION}

Findings indicate that balanced activities of creation of social values from one hand and commercialization of the effects are perception for sustainability strategy of academicians and managers that were interviewed. This research has a limitation in the number of subjects that were interviewed, and there should be performed additional research on the larger data set. There is still vast space for research in the context of the impact of managerial perception on open innovation concepts and public institutions' performance, and this paper is dealing with a potential research framework that might be more explored in the future. In further research, it would also be interesting to understand the routine dynamics of public institutions in terms of sustainability, taking into consideration managerial perception. In terms of practical implications, this research should enable the researchers, managers, public sector administrators, and personnel involved in organizational practices in public institutions to have a better understanding of the success of their projects. The managers can understand better that when they need to change/amend strategy while working on any project that involves open innovation in order to have a more sustainable environment. Perception of Project level efficiency should be considered as a way to improve the overall sustainability of public institutions.

ACKNOWLEDGEMENT

Thanks to Azar Alaie and Mansoor Ahmed, students of the postgraduate program at SKEMA Business School. 


\section{LITERATURE}

1. Chessbrough, H. W. (2003) Open Innovation: The New Imperative for Creating and Profiting from Technology. Harvard Business Press. USA

2. Mergel, I. (2018) "Open innovation in the public sector: drivers and barriers for the adoption of Challenge.gov." Public Management Review, 726-745.

3. Kim, R., Kapstein, E. (2014) Who benefits from intellectual property rights for agricultural innovation? The case of Ogura Oilseed Rape. Crop life\& Europa Bio. https://croplife.org/wp-content/uploads/2014/11/Ogura-Final-report.pdf, Accessed: 12/10/2019.

4. Ozleblelbici, Z., Cetin, S. (2015) The Role of Managerial Perception within Strategic Management: An Exploratory Overview of the Literature. Procedia - Social and Behavioral Sciences 207

5. Berelson, B., Steiner, G. A. (1964). Human behavior: An inventory of scientific findings. Harcourt, Brace \& World.

6. Mahoney, T. (1967) Managerial perceptions of organizational effectiveness, Management Science, 14(3).

7. Kotha, S., Dunbar, R.L.M. and Bird, A. (1995) Strategic action generation: a comparison of emphasis placed on generic competitive methods by the U.S. and Japanese managers, Strategic Management Journal, 16(3).

8. Luoma, M. (2005) Managers' perceptions of the strategic role of management development, Journal of Management Development, $7 / 8(24)$.

9. Bansal, P. (2002) The corporate challenges of sustainable development. Academy of Management Executive, 16.

10. Hahn, T., Pinkse, J., Preuss, L., Figge, F. (2015b) Tensions in corporate sustainability: Towards an integrative framework. Journal of Business Ethics, 127.

11. Dfori, D et al. (2014) Corporate social responsibility and financial performance: Fact or fiction? A look at Ghanaian banks. Acta Commercial. Vol 14, No1.

12. Schaltegger, S. Burritt, R. (2018) Business Cases and Corporate Engagement with Sustainability: Differentiating Ethical Motivations. Journal of Business Ethics, 2018, vol. 147, issue 2, No 1.

13. Eldridge, D. Nisar, T. (1995) Institutional development and sustainability: Approaches for public sector project organizations. Sustainable Development.Volume 3, Issue 3.

14. Edelbroek, R., Peters, P., Blomme, R. J. (2019) Engaging in open innovation: The mediating role of work engagement in the relationship between transformational and transactional leadership and the quality of the open innovation process as perceived by employees. Journal of General Management.

15. Sivam, A., Dieguez, T., Ferreira, L. P., Silva, F. (2019) Key settings for successful Open Innovation Arena. Journal of Computational Design and Engineering.

16. Singh, S. K., Gupta, S., Busso, D., Kamboj, S. (2019) Management capability in France-based multinationals innovation and organizational performance. Journal of Business Research.

17. INRA, (2019) http://institut.inra.fr/en, Assessed on 18/10/2019.

18. ISA, (2019) http://univ-cotedazur.fr/laboratories/isa\#.XdJg8TNKjIU, Assessed on 18/10/2019.
KVALITATIVNA ANALIZA EFEKATA MENADŽERSKE PERCEPCIJE NA OTVORENE INOVACIJE

\section{REZIME}

Ključne reči: Menadžerska percepcija, korporativna održivost, javne institucije, agrobiotehnologija.

Ovaj rad se bavi aspektima menadžerske percepcije i razumevanja uspeha koncepta otvorene inovacije i uticaja na održivost javnih institucija. Vodeći francuski (ali i globalni) agrobiotehnološki instituti izabrani su za kvalitativnu analizu kako bi razumeli položaj menadžera u smislu koncepta otvorene inovacije i kako bi to moglo doprineti održivosti javnih institucija. Nalazi ukazuju da su uravnotežene aktivnosti stvaranja društvenih vrednosti i komercijalizacija efekata percepcija strategije održivosti akademika i menadžera koji su intervjuisani. 